\title{
The Relationship between the Fluctuating Stock Market and the Macro-Economy: Taking the Shenzhen Index as an Example
}

\author{
Penglin Li, Huiyang Chen, Sijia Xu \\ Xi'an University of Science and Technology, Xi'an, China \\ Email: lplvip@163.com, 984679288@qq.com, xusijia2400@163.com
}

How to cite this paper: Li, P. L., Chen, H. Y., \& Xu, S. J. (2021). The Relationship between the Fluctuating Stock Market and the Macro-Economy: Taking the Shenzhen Index as an Example. Open Journal of Social Sciences, 9, 516-520.

https://doi.org/10.4236/jss.2021.93034

Received: March 5, 2021

Accepted: March 24, 2021

Published: March 31, 2021

\begin{abstract}
Foreign research on the stock market and macroeconomics has always believed that the two have a relatively strong correlation, but the domestic research results are completely irrelevant or weakly correlated. This article uses the Shenzhen Index as an example to analyze its relationship with the macro economy, and combines the irrational investment theory to analyze the reasons for the weak correlation between the macro economy and the stock market.
\end{abstract}

\section{Keywords}

Stock Market, Economy, EG Analysis

\section{Introduction}

Many literatures in the past have studied the relationship between GDP and macroeconomics. Relevant foreign literature all shows that the relationship between the stock market and the economy is relatively strong, but domestic research is not the case. Chen Shoudong and others analyzed the relationship between industrial added value and variables such as the Shanghai Stock Exchange Index and Industrial Index through a co-integration model and found that the real economy and the stock market are weakly correlated (Chen, Yi \& Liu, 2014). Li Yanhong and He Zhanghua analyzed the relationship between GDP and the amount of funds raised in the stock market through co-integration and error correction models, and concluded that the stock market and the economy are deviating ( $\mathrm{Li} \& \mathrm{He}$, 2009). Liu Shaobo and Ding Juhong analyzed the relationship between GDP per capita and the Shenzhen Chengcheng and Shanghai Composite Indexes through a typical analysis method and concluded that the stock 
market is not only closely related to the macro economy, but also can be used to predict the macro economy (Liu \& Ding, 2005). Zhang Peiyuan analyzed the correlation between the stock market return rate and some macroeconomic variables, and believed that the causality between economic variables and the stock market fluctuations was not obvious (Zhang, 2013).

In recent years, the economy has continued to develop and the stock market has been turbulent. Using Eviews9 to draw a comparison chart of GDP and Shenzhen Index is as follows:

From Figure 1, we can find that GDP shows a steady upward trend of fluctuations with the seasons, while the Shenzhen Component Index shows irregular fluctuations. "The stock market is risky, and you need to be cautious when entering the market." This just confirms the above figure, but from the overall trend, both are both. It is showing an upward trend, so an important hypothesis of this article is proposed: the two are relatively weakly related, but the economic development is still relatively affected by other factors.

\section{Data and Its Sources}

Since China's accession to the WTO in 2001, the economic model has changed from a closed planned economy to a more prosperous trade model. Therefore, the data selects quarterly data from 2002 to 2016.

In the past literature, GDP is often used as the only indicator to measure the macroeconomics, but this ignores the influence of factors such as inflation. Therefore, this article selects an indicator that can reflect both the degree of GDP fluctuations and the economy, namely the GDP index (GDP index). ). In addition, the Shenzhen Component Index (SZZ) is used to indicate the degree of volatility of the stock market, and total trade volume (TAR) and industrial value added (INDU) are selected as control variables.

The data on GDP index, total trade volume and industrial added value are all from the China Statistical Yearbook, and the data on the Shenzhen Index comes from the Guotaian Data Network.

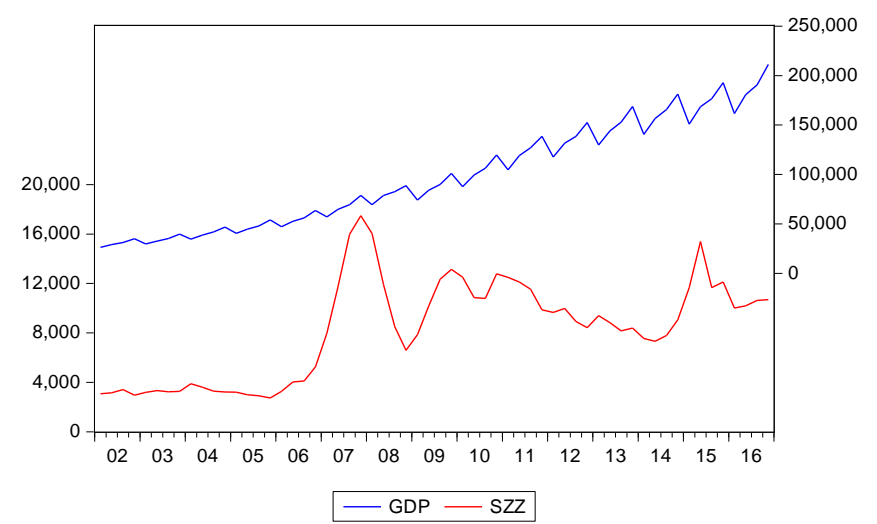

Note: The scale of GDP in the figure is on the right, and the scale of Shenzhen Index is on the left. Unit: GDP: 100 million yuan; Shenzhen Index: yuan.

Figure 1. Comparison of GDP and Shenzhen component index data from 2002 to 2016. 


\section{Empirical Research}

\subsection{Stationary Test}

The most important assumption implied by the regression model based on time series is that the data is stable. Therefore, this paper uses the ADF test to verify the stability of the data and uses the AIC and SC minimization principles to determine the maximum lag order. In addition, in order to eliminate the influence of heteroscedasticity and make the regression results valid, the logarithm of each variable is processed, namely LnGDP, LnSZZ, LnTRA and LnINDU. The specific test results are shown in Table 1 below.

From the statistical results shown above, the original data of GDP index, Shenzhen Component Index, total trade volume, and industrial added value are all unstable data, but the data after the first-order difference is stable, which means that these variables are the first-order difference is stable and satisfies the stationarity assumption of the regression model under the time series.

\subsection{Cointegration Test}

First, make a regression model of the variables. If the residuals of the residual series are stationary, it means that it has a long-term cointegration relationship, so that the following Granger causality analysis can be performed. The regression model is as follows:

$$
\text { LnGDP }=4.012+0.021 \mathrm{LnSZZ}-0.141 \mathrm{LnINDU}+0.098 \mathrm{LnTRADE}
$$

Second, we need to run a cointegration test. The regression model is as follows:

$$
\text { LnGDP }=4.012+0.021 \mathrm{LnSZZ}-0.141 \mathrm{LnINDU}+0.098
$$

If the residual of the residual sequence is stable, then it shows that it has a long-term co-integration relationship, so that we can carry out the subsequent Granger causality analysis of Percy Grainger. The cointegration test results are shown in Table 2.

Finally, we do the Percy Grainger test. The Percy Grainger causality test is a

Table 1. ADF test results of each variable.

\begin{tabular}{cccccc}
\hline \multirow{2}{*}{ variable } & ADF test & \multicolumn{2}{c}{ Tcritical statistics } & P value & in conclusion \\
\cline { 3 - 4 } & & $5 \%$ & $10 \%$ & & \\
\hline LnGDP & -2.461 & -2.913 & -2.606 & 0.506 & unstable \\
LnSZZ & -2.062 & -2.913 & -2.606 & 0.261 & unstable \\
LnTRA & -1.839 & -2.913 & -2.606 & 0.261 & unstable \\
LnINDU & -1.954 & -2.913 & -2.606 & 0.306 & unstable \\
$\triangle$ LnGDP & -6.723 & -2.913 & -2.594 & 0.000 & stable \\
$\triangle$ LnSZZ & -4.449 & -2.913 & -2.594 & 0.007 & stable \\
$\triangle$ LnTRA & -7.789 & -2.913 & -2.594 & 0.007 & stable \\
$\triangle$ LnINDU & -14.337 & -2.913 & -2.594 & 0.000 & stable \\
\hline
\end{tabular}

Note: $(\mathrm{a}, 0,2)$ means that the intercept item is selected and there is no trend item, the maximum lag order is $2 ;(a, 0,0)$ is the same, but the lag order is 0 . 
Table 2. ADF test results of the residual sequence of the regression equation.

\begin{tabular}{ccccc}
\hline \multirow{2}{*}{$\begin{array}{c}\text { ADF stationarity } \\
\text { test result }\end{array}$} & \multicolumn{2}{c}{$\mathrm{t}$ critical statistics } & \multirow{2}{*}{ P value } & test result \\
\cline { 2 - 3 } & $5 \%$ & $10 \%$ & & \\
\hline-3.2702 & -1.9467 & -1.6131 & 0.0015 & smooth \\
\hline
\end{tabular}

Table 3. Granger causality test.

\begin{tabular}{|c|c|c|c|c|}
\hline Null hypothesis & $\begin{array}{c}\text { Number of } \\
\text { samples }\end{array}$ & $\begin{array}{l}\text { Lag } \\
\text { order }\end{array}$ & $\begin{array}{c}\mathrm{F} \\
\text { statistics }\end{array}$ & possibility \\
\hline LnSZZ is not a Granger reason for LnGDP & 58 & 2 & 10.7284 & 0.0001 \\
\hline LnGDP is not LnSZZ reason for LnGDP & & & 0.3006 & 0.7416 \\
\hline LnINDU is notLnGDP reason for LnGDP & 58 & 2 & 2.8027 & 0.0697 \\
\hline LnGDP is not LnINDU reason for LnGDP & & & 0.8707 & 0.4245 \\
\hline LnTRADE is not LnGDP reason for LnGDP & 58 & 2 & 3.0882 & 0.0539 \\
\hline LnGDP is not LnTRADE reason for LnGDP & & & 1.9033 & 0.1591 \\
\hline LnINDU is not LnSZZ reason for LnGDP & 58 & 2 & 2.6281 & 0.0816 \\
\hline LnSZZ is not LnINDU reason for LnGDP & & & 1.3824 & 0.2599 \\
\hline LnTRADE is not LnSZZ reason for LnGDP & 58 & 2 & 4.4527 & 0.0163 \\
\hline $\mathrm{LnSZZ}$ is not LnTRADE reason for LnGDP & & & 2.5453 & 0.0880 \\
\hline LnTRADE is not LnINDU reason for LnGDP & 58 & 2 & 23.8997 & 0.0000 \\
\hline LnINDU is not LnTRADE reason for LnGDP & & & 11.0348 & 0.0001 \\
\hline
\end{tabular}

causal prediction based on stationary time series data, which has some reference significance in the econometrics. Percy Grainger, the results of the causality test are shown in Table 3.

\subsection{GRANGER Inspection}

Granger causality test is a causal relationship prediction based on stationary time series data, which has certain reference significance in econometrics. The results of Granger Causality Test are shown in Table 3.

It can be seen from the above test results that the total trade volume and the industrial added value have a two-way Granger causality, which means that they have a positive effect on each other. The Shenzhen Component Index has a oneway Granger causality relationship to the macro economy, and from the above regression equation we can know that the relationship is relatively weak. In addition, the total trade volume also has a certain promotion effect on the macro economy, and although the industrial value added is likely to affect the macro economy, the coefficient of the industrial value added in the regression equation is negative, so it will have a negative effect on the macro economy influences.

\section{Conclusion}

The stock market is an emerging market in my country, and its development is 
not perfect. Although GDP can affect the stock market, the stock market does not have a complete structural system, which makes the information transmitted by the macro economy to the stock market untrue and reliable. Disconnected, investors have no specific investment orientation, and irrational investment behaviors have appeared. Investors have a "gambling" mentality to set foot in the stock market, and there are more retail investors, and the phenomenon of stock speculation has intensified, which has made the stock market more turbulent and bubbled very serious.

In addition, in my country, private manufacturing and Sino-foreign joint ventures contribute to the GDP to a relatively large extent, while the listed companies are mostly state-owned enterprises, which are not the main contributors to my country's economy, so their stocks cannot objectively reflect my country's economy situation. Even though most of the foreign literatures have a strong correlation between the analysis results of the two, they do not regard the stock market as the most important factor reflecting the economy, which shows that the relationship between the two is not far-reaching and stable.

The pricing of stocks depends to a large extent on interest rates. As interest rates rise, the stock price becomes lower, and when interest rates decrease, the stock price rises. However, the impact of interest rates on the economy is not significant, leading to a disconnect between the two.

\section{Conflicts of Interest}

The authors declare no conflicts of interest regarding the publication of this paper.

\section{References}

Chen, S. D., Yi, X. L., \& Liu, Y. (2014). Research on the Asymmetric Effect of the Correlation between China's Stock Market and the Macro Economy under Policy Uncertainty. Contemporary Finance, 1, 45-55.

Li, Y. H., \& He, G. H. (2009). Analysis of the Relevance between My Country's Stock Market and the Real Economy-An Empirical Study Based on Cointegration Model. Economic Frontiers, 6, 30-38.

Liu, S. B., \& Ding, J. H. (2005). “Three-Stage Evolution Path” Analysis of the Correlation between my Country's Stock Market and Macroeconomics. Financial Research, 7, 57-66.

Zhang, P. Y. (2013). Research on the Correlation between China's Stock Market and Macroeconomics. The Party School of the Central Committee of the Communist Party of China. 